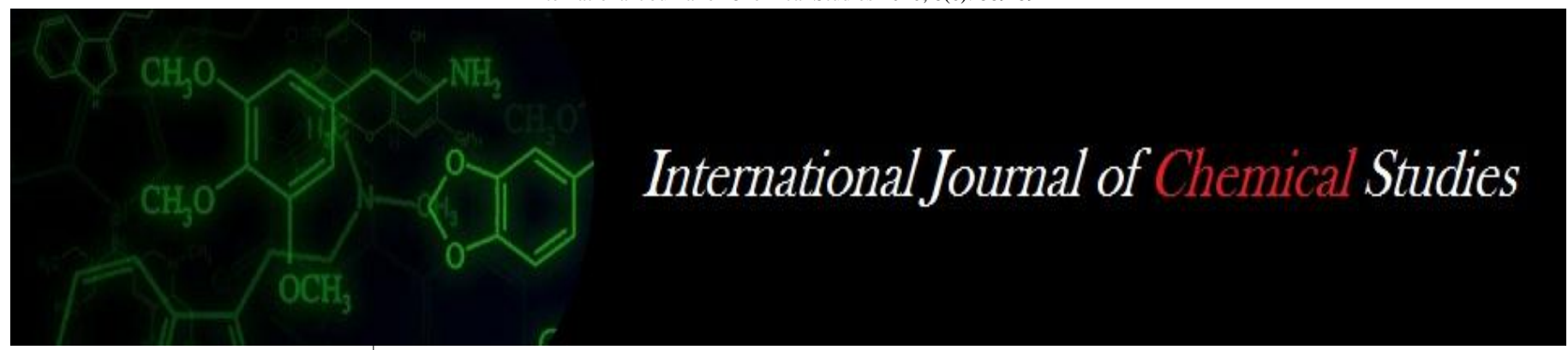

P-ISSN: 2349-8528

E-ISSN: 2321-4902

www.chemijournal.com

IJCS 2020; 8(6): 889-891

(C) 2020 IJCS

Received: 25-08-2020

Accepted: 18-10-2020

\section{Mohammad Rizwan}

Department of Entomology, sardar Vallabhbhai Patel

University of Agriculture And

Technology, Meerut, Uttar

Pradesh, India

\section{SK Sachan}

Department of Entomology, sardar Vallabhbhai Patel

University of Agriculture And

Technology, Meerut, Uttar

Pradesh, India

\section{Rajendra Singh}

Department of Entomology, sardar Vallabhbhai Patel

University of Agriculture And

Technology, Meerut, Uttar

Pradesh, India

\section{Gaje Singh}

Department of Entomology, Sardar Vallabhbhai Patel

University of Agriculture And

Technology, Meerut, Uttar

Pradesh, India

\section{Gopal Singh}

Department of Plant Pathology,

Sardar Vallabhbhai Patel

University of Agriculture and

Technology, Meerut, Uttar

Pradesh, India

\section{RB Yadav}

Department of Agronomy, Sardar Vallabhbhai Patel University of Agriculture and Technology, Meerut, Uttar Pradesh, India
Corresponding Author: Mohammad Rizwan Department of Entomology, sardar Vallabhbhai Patel University of Agriculture And Technology, Meerut, Uttar Pradesh, India

\section{Population buildup of yellow stem borer, Scirpophaga incertulas (Walker) of basmati rice in relation to abiotic factors}

\author{
Mohammad Rizwan, SK Sachan, Rajendra Singh, Gaje Singh, Gopal \\ Singh and RB Yadav
}

DOI: $\underline{\text { htps://doi.org/10.22271/chemi.2020.v8.i6m.10880 }}$

\begin{abstract}
The population buildup of yellow stem borer, Scirpophaga incertulas was experimented during Kharif, 2018 and 2019 at thr CRC farm of Sardar Vallabhbhai Patel University of Agriculture and Technology, Meerut, U.P. The infestation of stem borer was recorded on variety Pusa Basmati-1 at weekly intervals from $32^{\text {nd }}$ standard week and continued till the $43^{\text {rd }}$ standard week and $33^{\text {rd }}$ standard week and continued till the $43^{\text {rd }}$ standard week during Kharif 2018 and 2019, respectively. The infestation of stem borer recorded as dead hearts /white ear heads and increased from third week of August and reached its peak $(13.40 \%)$ in $41^{\text {st }}$ standard week (Second week of October) and reached its peak $(12.35 \%)$ in $36^{\text {th }}$ standard week (second week of September) during Kharif 2018 and 2019, respectively.
\end{abstract}

Keywords: Population buildup, abiotic factors, basmati rice and yellow stem borer

\section{Introduction}

Rice also known as the princess of cereals is staple food of 65 percent of the world's population and contributes about $23 \%$ of the total calories requirement of mankind (Dhaliwal, 2005) ${ }^{[2]}$. Rice is grown in diverse growing conditions such as irrigated, rainfed low land, rainfed upland and flood prone ecosystem. In India, area under rice cultivation is 44.50 million ha with production of 115.63 million tones and productivity of $2.39 \mathrm{t} / \mathrm{ha}$. Uttar Pradesh is the second largest producer of rice after West Bengal occupying 5.87 million ha area with annual production of 12.17 million tones and average productivity of $2.07 \mathrm{t} / \mathrm{ha}$. In National food security the contribution of rice is very important since it occupy a good acreage. Although, the present level of national productivity is enough to ensure food security but for future with increasing population we can not rely on it and we have to improve productivity at state and national level (DAC and FW, 2019) ${ }^{[3]}$.

Basmati rice which is mainly known for its aroma, fragrance and super fine kernels grown mainly in the western part of Uttar Pradesh, Uttarakhand, Haryana and Panjab account for $92 \%$ of the total basmati rice production. In fact, Indian basmati rice is well recognized in the international market. Realizing the importance of crop and availability of irrigation water and best climatic conditions, the government of India has identified western Uttar Pradesh as one of the potential basmati rice export zone.

Among more than hundred species of insects that feed and breed on rice crops, about 20 are of major importance. These pests occur regularly and ravage the crop from seedling stage to maturity of the crop (Rana et al., 2017) ${ }^{[8]}$. Yellow stem borer Scirpophaga incertulas (Pyralidae: Lepidoptera) is one of the widely distributed, dominant and most destructive pest of paddy in the Indian subcontinent. The freshly hatched larvae bore into stem and starts to feed internally causing death of central shoot called "dead heart" or drying of the central tiller during vegetative stage and white earheads at milky stage, respectively. This results in chaffy grains at reproductive stage (Hugar et al., 2009) ${ }^{[4]}$. Presence of entrance or exit holes on the stem can be seen. Faecal matters are found inside the damaged stem.

The intensity of pest damage varies is different seasons, years and agro climatic zones due to variability in weather parameters and biotic mortality factors. Understanding of pest population dynamics in relation to weather factors can help in better management of pests. 
Besides, knowledge of the seasonal abundance and pest build up trend is essential to ensure timely preparedness to tackle pest problems and prevent crop losses.

\section{Materials and Methods}

The experiment was laid out in randomized block design (RBD) with three replications of variety Pusa Basmati-1. There were total seven treatments including control. The plot size for each treatment was kept $5 \times 4 \mathrm{~m}^{2}$ with spacing between row to row $20 \mathrm{~cm}$ and plant to plant $20 \mathrm{~cm}$, respectively. All the recommended agronomical practices were adopted in raising the crop except package recommended for insect pest managements. The population fluctuation of yellow stem borer, the random sampling was carried out. Ten hills were tagged out randomly from each plot of the untreated trial. These hills were observed regularly in the morning hours at weekly intervals starting from transplanting till the harvest of crop. Dead hearts/white ear heads and larval population of yellow stem borer was recorded per hill. The meteorological data was also recorded throughout the crop season. Meteorological data pertaining to temperature, relative humidity and rainfall during experimental period was obtained from the meteorological observatory of Sardar Vallabhbhai Patel University of Agriculture and Technology, Meerut, U.P.

\section{Results and Discussion Kharif 2018}

The infestation of yellow stem borer appeared first on $32^{\text {nd }}$ standard week and continued till the $43^{\text {rd }}$ standard week during Kharif 2018 (Table 1). The infestation of stem borer recorded as dead hearts /white ear heads ranged from 3.86 to 13.40 percent during Kharif 2018. The infestation of stem borer increased from third week of August and reached its peak $(13.40 \%)$ during $41^{\text {st }}$ standard week (Second week of October). During this period the weather parameters like temperature, relative humidity and rainfall ranged from 18.71 to $34.14^{\circ} \mathrm{C}, 55.00$ to $87.00 \%$ and $0.49 \mathrm{~mm}$, respectively. The stem borer infestation suddenly decreased after middle of October i.e. $42^{\text {nd }}$ and $43^{\text {rd }}$ standard week and this might be due to the no emergence of new leaves. The infestation was high in the absence of rains.

\section{Kharif 2019}

Infestation on yellow stem borer started first on $33^{\text {rd }}$ standard week and continued till the $43^{\text {rd }}$ standard week during Kharif 2019 (Table 2). The infestation of stem borer recorded as dead hearts /white ear heads ranged from 3.27 to 12.35 percent during Kharif 2019. The infestation of stem borer increased from third week of August and reached its peak $(12.35 \%)$ during $36^{\text {th }}$ standard week (second week of September). During this period the weather parameters like temperature, relative humidity and rainfall ranged from 25.37 to $34.37^{\circ} \mathrm{C}, 75.99$ to $95.76 \%$ and $0.00 \mathrm{~mm}$, respectively. The stem borer infestation suddenly decreased after middle of October i.e. $42^{\text {nd }}$ and $43^{\text {rd }}$ standard week and this might be due to the no emergence of new leaves.

\section{Pooled (Kharif, 2018 and 2019)}

Perusal of pooled infestation of both the years (Kharif, 2018 and 2019) showed that the infestation of yellow stem borer appeared first on $32^{\text {nd }}$ standard week and continued till the $43^{\text {rd }}$ standard week (Table 3). The infestation of stem borer recorded as dead hearts /white ear heads ranged from 3.56 to 12.35 percent during the years. The infestation of stem borer increased from second week of August and reached its peak $(12.87 \%)$ during $36^{\text {th }}$ standard week (second week of September). During this period the weather parameters like temperature, relative humidity and rainfall ranged from 26.04 to $35.75^{\circ} \mathrm{C}, 64.42$ to $95.02 \%$ and $5.91 \mathrm{~mm}$, respectively. The stem borer infestation suddenly decreased after middle of October i.e. $42^{\text {nd }}$ and $43^{\text {rd }}$ standard week and this might be due to the no emergence of new leaves.

The present findings uphold the views of Kharat (2006) ${ }^{[6]}$ who reported that the incidence of stem borer increased from the $32^{\text {nd }}$ standard week and it started declining from the $42^{\text {nd }}$ standard week. The correlation matrix indicated that rainfall, maximum temperature and number of rainy days exhibited negative correlation with incidence of stem borer, while the incidence was non-significant positively correlation with minimum temperature, average temperature, morning, evening, average humidity. Kakde and Patel (2014) ${ }^{[5]}$ also reported that the incidence of stem borer initiated from the $32^{\text {nd }}$ standard meteorological week (SMW) i.e. the first week of August $(0.71 \% \mathrm{DH})$ with the peak infestation at $36^{\text {th }} \mathrm{SMW}$ (5.17\% DH) during Kharif 2012. Adiroubane and Raja (2007) ${ }^{[1]}$ observed that high pest incidence of rice yellow stem borer was recorded during month of August- September (Kharif, 2006). Kumar et al. (2015) ${ }^{[7]}$ reported that yellow stem borer population had positive correlation with maximum temperature $\left({ }^{\circ} \mathrm{C}\right)$, minimum temperature $\left({ }^{\circ} \mathrm{C}\right)$, morning relative humidity $\%$, evening relative humidity $\%$ and rainfall $(\mathrm{mm})$ were positively correlated to the tune of $0.273,0.453$, $0.075,0.478$ and 0.339 , respectively.

\section{Conclusion}

The infestation of yellow stem borer started from $32^{\text {nd }}$ standard week and continued till the $43^{\text {rd }}$ standard week with the maximum infestation $(13.40 \%$ dead hearts $)$ in $41^{\text {st }}$ standard week (Second week of October) and maximum infestation $\left(12.35 \%\right.$ dead hearts) in $36^{\text {th }}$ standard week (second week of September) during Kharif, 2018 and 2019, respectively. From the present investigation it may be concluded that infestation of yellow stem borer $S$. incertulas was influenced by one or more abiotic factors and crop stages which can be utilized for decision making.

Table 1: Population build-up of rice stem borer, S. incertulas in relation to abiotic factors during Kharif 2018

\begin{tabular}{|c|c|c|c|c|c|c|c|c|c|c|}
\hline \multirow{3}{*}{$\begin{array}{l}\text { S. } \\
\text { No }\end{array}$} & \multirow{3}{*}{$\begin{array}{l}\text { S. } \\
\text { W. }\end{array}$} & \multirow{3}{*}{ Dates } & \multirow{3}{*}{$\begin{array}{c}\text { Dead hearts/White ear } \\
\text { head }(\%)\end{array}$} & \multicolumn{7}{|c|}{ Meteorological parameters } \\
\hline & & & & \multicolumn{3}{|c|}{ Temperature $\left({ }^{0} \mathrm{C}\right)$} & \multicolumn{3}{|c|}{ Relative Humidity (\%) } & \multirow{2}{*}{$\begin{array}{c}\text { Rainfall } \\
(\mathbf{m m})\end{array}$} \\
\hline & & & & Max. & Min. & Mean & Morn. & Eve. & Mean & \\
\hline 1. & 30 & 23 July - 29 July & 0.00 & 34.00 & 26.71 & 30.35 & 91.29 & 59.57 & 75.43 & 52.77 \\
\hline 2. & 31 & 30 July - 05 Aug & 0.00 & 36.57 & 26.71 & 31.64 & 94.29 & 51.43 & 72.86 & 0.00 \\
\hline 3. & 32 & 06 Aug - 12 Aug & 4.11 & 37.14 & 27.29 & 32.21 & 93.57 & 52.86 & 73.21 & 8.04 \\
\hline 4. & 33 & 13 Aug - 19 Aug & 7.80 & 39.00 & 28.29 & 33.64 & 93.29 & 42.57 & 67.93 & 3.29 \\
\hline 5. & 34 & $20 \mathrm{Aug}-26 \mathrm{Aug}$ & 9.72 & 37.00 & 27.00 & 32.00 & 92.43 & 54.43 & 73.43 & 3.14 \\
\hline 6. & 35 & 27 Aug - 02 Sep & 11.12 & 39.14 & 28.57 & 33.85 & 91.43 & 44.14 & 67.78 & 28.24 \\
\hline 7. & 36 & 03 Sep - 09 Sep & 12.36 & 37.14 & 26.71 & 31.92 & 94.29 & 52.86 & 73.57 & 11.83 \\
\hline 8. & 37 & $10 \mathrm{Sep}-16 \mathrm{Sep}$ & 11.30 & 38.57 & 27.86 & 33.21 & 88.71 & 50.57 & 69.64 & 1.39 \\
\hline
\end{tabular}




\begin{tabular}{|c|c|c|c|c|c|c|c|c|c|c|}
\hline 9. & 38 & 17 Sep -23 Sep & 9.90 & 35.14 & 21.90 & 28.52 & 87.86 & 55.86 & 71.86 & 1.86 \\
\hline 10. & 39 & 24 Sep -30 Sep & 10.70 & 32.57 & 23.00 & 27.78 & 94.00 & 72.14 & 83.07 & 5.29 \\
\hline 11. & 40 & 01 Oct -07 Oct & 12.10 & 35.86 & 20.71 & 28.28 & 96.14 & 58.86 & 77.50 & 0.00 \\
\hline 12. & 41 & 08 Oct -14 Oct & 13.40 & 34.14 & 18.71 & 26.42 & 87.00 & 55.00 & 71.00 & 0.49 \\
\hline 13. & 42 & 15 Oct -21 Oct & 7.60 & 34.43 & 15.00 & 24.71 & 90.00 & 51.00 & 70.50 & 0.20 \\
\hline 14. & 43 & 22 Oct -28 Oct & 3.86 & 32.71 & 13.43 & 23.07 & 90.57 & 49.14 & 69.85 & 0.00 \\
\hline 15. & 44 & 29 Oct -04 Nov & 0.00 & 31.71 & 12.00 & 21.85 & 91.14 & 45.43 & 68.28 & 0.46 \\
\hline
\end{tabular}

Table 2: Population build-up of rice stem borer, S. incertulas in relation to abiotic factors during Kharif 2019

\begin{tabular}{|c|c|c|c|c|c|c|c|c|c|c|}
\hline \multirow{3}{*}{$\begin{array}{l}\text { S. } \\
\text { No. }\end{array}$} & \multirow{3}{*}{$\begin{array}{l}\text { S. } \\
\text { W. }\end{array}$} & \multirow{3}{*}{ Date } & \multirow{3}{*}{$\begin{array}{l}\text { Dead hearts/White } \\
\text { ear head }(\%)\end{array}$} & \multicolumn{7}{|c|}{ Meteorological parameters } \\
\hline & & & & \multicolumn{3}{|c|}{ Temperature $\left({ }^{0} \mathrm{C}\right)$} & \multicolumn{3}{|c|}{$\begin{array}{c}\text { Relative Humidity } \\
(\%)\end{array}$} & \multirow{2}{*}{$\begin{array}{c}\text { Rainfall } \\
(\mathbf{m m})\end{array}$} \\
\hline & & & & Max. & Min. & Mean & Mor. & Eve. & Mean & \\
\hline 1. & 30 & 23 July - 29 July & 0.00 & 35.29 & 24.50 & 29.89 & 93.71 & 68.00 & 80.85 & 21.43 \\
\hline 2. & 31 & 30 July - 05 Aug & 0.00 & 35.86 & 25.24 & 30.55 & 90.00 & 46.57 & 68.28 & 6.86 \\
\hline 3. & 32 & 06 Aug - 12 Aug & 0.00 & 34.03 & 25.19 & 29.61 & 94.76 & 67.63 & 81.19 & 13.14 \\
\hline 4. & 33 & 13 Aug - 19 Aug & 3.79 & 32.00 & 24.39 & 28.19 & 94.99 & 86.69 & 90.84 & 9.14 \\
\hline 5. & 34 & 20 Aug - 26 Aug & 5.90 & 33.71 & 24.53 & 29.12 & 94.83 & 71.34 & 83.08 & 3.20 \\
\hline 6. & 35 & 27 Aug - 02 Sep & 9.80 & 34.83 & 25.21 & 30.02 & 93.34 & 70.73 & 82.03 & 12.84 \\
\hline 7. & 36 & $03 \mathrm{Sep}-09 \mathrm{Sep}$ & 12.35 & 34.37 & 25.37 & 29.87 & 95.76 & 75.99 & 85.87 & 0.00 \\
\hline 8. & 37 & $10 \mathrm{Sep}-16 \mathrm{Sep}$ & 10.21 & 34.53 & 25.01 & 29.77 & 94.77 & 71.40 & 83.08 & 0.00 \\
\hline 9. & 38 & $17 \mathrm{Sep}-23 \mathrm{Sep}$ & 8.26 & 33.50 & 23.21 & 28.35 & 93.66 & 62.41 & 78.03 & 0.33 \\
\hline 10. & 39 & $24 \mathrm{Sep}-30 \mathrm{Sep}$ & 8.70 & 31.40 & 22.59 & 26.99 & 94.84 & 72.31 & 83.57 & 2.06 \\
\hline 11. & 40 & $01 \mathrm{Oct}-07 \mathrm{Oct}$ & 9.81 & 31.21 & 20.56 & 25.88 & 95.19 & 60.71 & 77.95 & 3.27 \\
\hline 12. & 41 & 08 Oct -14 Oct & 10.35 & 31.94 & 18.94 & 25.44 & 93.53 & 57.01 & 75.27 & 0.00 \\
\hline 13. & 42 & $15 \mathrm{Oct}-21 \mathrm{Oct}$ & 7.24 & 32.04 & 18.47 & 25.25 & 94.74 & 60.96 & 77.85 & 0.00 \\
\hline 14. & 43 & $22 \mathrm{Oct}-28 \mathrm{Oct}$ & 3.27 & 30.07 & 15.87 & 22.97 & 94.19 & 50.86 & 72.52 & 0.00 \\
\hline 15. & 44 & 29 Oct -04 Nov & 0.00 & 29.77 & 15.76 & 22.76 & 93.74 & 53.74 & 73.74 & 0.00 \\
\hline
\end{tabular}

Table 3: Pooled data for population build-up of rice stem borer, S. incertulas in relation to abiotic factors during Kharif, 2018 and 2019

\begin{tabular}{|c|c|c|c|c|c|c|c|c|c|}
\hline \multirow{3}{*}{ S. W. } & \multirow{3}{*}{ Dates } & \multirow{3}{*}{ Dead hearts/White ear head (\%) } & \multicolumn{7}{|c|}{ Meteorological parameters } \\
\hline & & & \multicolumn{3}{|c|}{ Temperature $\left({ }^{0} \mathrm{C}\right)$} & \multicolumn{3}{|c|}{ Relative Humidity (\%) } & \multirow{2}{*}{ Rainfall (mm) } \\
\hline & & & Max. & Min. & Mean & Mor. & Eve. & Mean & \\
\hline 30 & 23 July - 29 July & 0.00 & 34.64 & 25.60 & 30.12 & 92.5 & 63.78 & 78.14 & 37.10 \\
\hline 31 & 30 July - 05 Aug & 0.00 & 36.21 & 25.97 & 31.09 & 92.14 & 49.00 & 70.57 & 3.43 \\
\hline 32 & 06 Aug - 12 Aug & 2.05 & 35.60 & 26.24 & 30.91 & 94.16 & 60.24 & 77.20 & 10.59 \\
\hline 33 & 13 Aug - 19 Aug & 5.80 & 35.50 & 26.34 & 30.91 & 94.14 & 64.63 & 79.38 & 6.21 \\
\hline 34 & $20 \mathrm{Aug}-26 \mathrm{Aug}$ & 7.81 & 35.35 & 25.76 & 30.56 & 93.63 & 62.90 & 78.25 & 3.17 \\
\hline 35 & 27 Aug -02 Sep & 10.46 & 36.90 & 26.89 & 31.93 & 92.38 & 57.43 & 74.90 & 20.54 \\
\hline 36 & $03 \mathrm{Sep}-09 \mathrm{Sep}$ & 12.87 & 35.75 & 26.04 & 30.90 & 95.02 & 64.42 & 79.72 & 5.91 \\
\hline 37 & $10 \mathrm{Sep}-16 \mathrm{Sep}$ & 10.75 & 36.55 & 26.43 & 31.49 & 91.74 & 60.99 & 76.36 & 0.69 \\
\hline 38 & $17 \mathrm{Sep}-23 \mathrm{Sep}$ & 9.08 & 34.32 & 22.55 & 28.43 & 90.76 & 59.13 & 74.94 & 1.09 \\
\hline 39 & $24 \mathrm{Sep}-30 \mathrm{Sep}$ & 9.70 & 31.90 & 22.80 & 27.38 & 94.42 & 72.22 & 83.32 & 3.67 \\
\hline 40 & $01 \mathrm{Oct}-07 \mathrm{Oct}$ & 10.95 & 33.53 & 20.63 & 27.08 & 95.66 & 59.78 & 77.72 & 1.63 \\
\hline 41 & 08 Oct -14 Oct & 11.88 & 33.04 & 18.82 & 25.93 & 90.26 & 56.00 & 73.13 & 0.24 \\
\hline 42 & $15 \mathrm{Oct}-21 \mathrm{Oct}$ & 7.42 & 33.23 & 16.73 & 24.98 & 92.37 & 55.98 & 74.17 & 0.10 \\
\hline 43 & $22 \mathrm{Oct}-28 \mathrm{Oct}$ & 3.56 & 31.39 & 14.65 & 23.02 & 92.38 & 50.00 & 71.18 & 0.00 \\
\hline 44 & $29 \mathrm{Oct}-04 \mathrm{Nov}$ & 0.00 & 30.74 & 13.88 & 22.30 & 92.44 & 49.58 & 71.01 & 0.23 \\
\hline
\end{tabular}

\section{References}

1. Adiroubane D, Raja K. Influence of weather parameters on the occurrence of rice yellow stem borer, Scirpophaga incertulas (Walker). Journal of Rice Research 2007;3(1):5-9.

2. Dhaliwal GS. Field evaluation of azadirachtin-rich neem formulations against Cnaphalocrocis medinalis (Guenee) and Scirpophaga incertulas (Walker) on rice. Pesticide Research Jaurnal, 2005;14(1):69-76.

3. Directorate of Economics and Statistics, DAC \& FW 2019. www.dac\&ew.gov.in.com

4. Hugar SV, Venkatesh H, Hanumantha SBC, Pradeep S. Influence of weather factors on the infestation of yellow stem borer, Scirpophaga incertulas walker in aerobic rice. Asian Journal of Environmental Science, 2009;4(2):151-154.

5. Kakde AM, Patel KG. Seasonal incidence of rice yellow stem borer (Scirpophaga incertulas Walkar) in relation to conventional and SRI Methods of planting and its correlation with weather parameters. IOSR Journal of Agriculture and Veterinary Science, 2014;7(6):05-10.

6. Kharat SR. Influence of nutrients on incidence of insect pest complex of paddy and their management. M.Sc. (Ag) thesis submitted to Navsari Agricultural University, Navsari (Gujarat) 2006.

7. Kumar A, Misra AK, Satyanarayana P, Kumar J. Population dynamics and management of yellow stem borer (Scirpophaga incertulas Walker) with insect sexpheromone trap. International Journal of Plant Protection 2015;8(1):157-161.

8. Rana R, Singh G, Kumar A, Tanwar, Kumar R. Effect of weather parameters on the infestation of yellow stem borer, Scirpophaga incertulas (Walker) in basmati rice. Journal of Entomology and Zoology Studies 2017;5(3):24-27. 